\title{
The effect of undergone bypass surgery on the percutaneous coronary intervention results / does previous coronary artery bypass surgery complicate the subsequent percutaneous coronary intervention?
}

\section{Geçirillmiş baypas cerrahisinin perkütan koroner girişim sonuçları üzerine olan etkisi / geçirilmiş koroner arter baypas cerrahisi sonrasında yapılan perkütan koroner girişimleri güçleştirir mi?}

\section{Mehmet Balin}

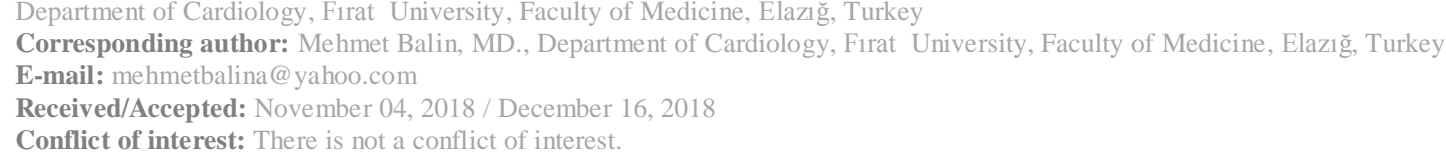

\section{SUMMARY}

Objective: Recurrent revascularization is frequently needed in despite to the modern treatment options of coronary artery disease. Recurrent revascularization has need special caution in the setting of previous coronary artery bypass surgery $(\mathrm{CABG})$. There are very few studies to investigate possible adverse effects of prior CABG on percutaneous coronary interventions (PCI). This study investigated that PCI results of the patients with prior CABG.

Method: Patients who underwent PCI screened retrospectively. Consecutive 100 patients had been prior PCI (group 1), and 100 patients had been prior CABG (group 2) were enrolled to the study. The patients were not enrolled in the study; index PCI underwent bypass graft or total occluded lesion or instant lesion or in the setting of ST elevation myocardial infarction or bifurcation stenting was done.

Results: Group 1 and group 2 were similar in terms of age and gender. No statistically significant difference was observed between other demographic features. The lesion severity was not significantly different between the groups. In the $\mathrm{CABG}$ group, the intervention was more frequent to the circumflex artery lesion; while in the PCI group, intervention to the left anterior descending artery lesion was more frequent. Factors that made the procedure difficult were similar in both groups. There was no significant difference between the two groups regarding lesions longer than $20 \mathrm{~mm}$ and diffuse coronary artery disease. Balloon and stenting were more frequent in the CABG group, and direct stenting was more frequent in the PCI group $(\mathrm{p}<0.05)$ Balloon dilatation was found to be more frequent in the $\mathrm{CABG}$ group. The duration of the procedure, number of angiographic frames and films, amount of contrast material used were significantly higher in the $\mathrm{CABG}$ group, as the difference between the two groups was not significant regarding balloon pressures applied during stenting. Previous CABG history was found to be an independent variable for the duration of the procedure and the number of angiographic frames. Prior CABG also has a significant correlation with prolonged intervention duration, radiopaque volume, and cine-angiography film and frame counts when controlling for intervened artery and prior index intervention time interval.

Conclusions: PCI was associated with prolonged intervention duration, higher radiopaque volume and higher radiation exposure when implanted in patients with prior $\mathrm{CABG}$. The physician should be alert and precautionary for more complex PCI in patients with prior CABG.

Keywords: coronary artery disease, coronary artery bypass grafting, percutaneous coronary intervention 
ÖZET

Amaç: Koroner arter hastalığında modern tedavi seçeneklerine rağmen tekrarlayan revaskülarizasyon sıklıkla gerekir. Tekrarlayan revaskülarizasyon, koroner baypas cerrahisi (KABC) geçirenlerde özel dikkat gerektirir. Önceki KABC'nin perkütan koroner girişimler (PKG) üzerindeki olası yan etkilerini araştırmak için yapilmış çok az sayıda çalışma mevcuttur. Bu çalışmada, koroner baypaslı hastaların PKG sonuçları araştıııldı.

Yöntem: PKG uygulanan tüm hastalar retrospektif olarak tarandı. Daha önce PKG öyküsü olan ardışık 100 hasta (1. grup) ile önceden KABC öyküsü olan 100 hasta (2. grup) çalışmaya dahil edildi. Tam oklüde ve ya stent içi lezyona ya da baypas grefte uygulanmış PKG ile ST elevasyonlu miyokardiyal infarktüs nedeniyle başvuran veya bifurkasyon stentleme uygulanan hastalar çalıșmaya dahil edilmedi.

Bulgular: Yaş ve cinsiyet açısından 1. ve 2. grup benzerdi. Diğer demografik özellikler açısından da istatistiksel olarak anlamlı fark yoktu. Lezyon ağırlığı da iki grup arasında anlamlı derecede farklı değildi. KABC grubunda sirkumfleks arter lezyonuna girişim daha sıkken, PKG grubunda sol ön inen arter lezyonuna girişim sıktı. Her iki grupta prosedürü zorlaştıran faktörler benzerdi. Her iki grup arasında 20 mm'den uzun lezyon varlığı ve diffüz koroner arter hastalığı açısından anlamlı fark yoktu. KABC grubunda balon ve stentleme daha sıkken, PKG grubunda direkt stentleme daha siktı $(\mathrm{p}<0.05)$. KABC grubunda balon dilatasyonun daha sik olduğu saptandı. Prosedürün süresi, alınan anjiyografik film sayısı ile kullanılan kontrast maddenin miktarı KABC grubunda istatistiksel olarak daha yüksekken, iki grup arasındaki stentleme sırasında uygulanan balon basınçları açısından anlamlı fark yoktu. Önceki KABC öyküsü; prosedürün süresi ve alınan anjiyografik film sayısı için bağımsız bir değişken olarak saptandı. Girişim uygulanmış arter ve önceki indeks girişim zaman aralığı kontrol edildiğinde; önceki KABC'nin benzer şekilde uzamış girişim süresi, kullanılan radyoopak miktarı, sine- anjiyografi görüntü sayısı ile anlamlı ilişkisi vardı.

Sonuç: PKG, önceden KABC öyküsü olan hastalara uygulandığında; uzamış girişim süresi, daha çok kullanılan radyoopak miktarı ve daha uzun süre radyasyon maruziyeti ile ilişkiliydi. Bu nedenle klinisyen KABC öyküsü olan hastalarda daha karmașık PKG için daha dikkatli ve tedbirli olmalıdır.

Anahtar sözcükler: Koroner arter hastalığı, koroner arter baypas greftleme, perkütan koroner girişim

\section{INTRODUCTION}

Coronary Artery Disease (CAD) is the most important cause of mortality and morbidity all over the world ${ }^{1}$. In the last 60 years, coronary artery bypass grafting (CABG) surgery is widely performed to CAD patients. Percutaneous coronary intervention (PCI) has been used clinically for the last 30 years and has become an alternative for CABG for most lesions ${ }^{2}$. Because atherosclerosis is a dynamic process, some patients who have been previously revascularized require re-intervention ${ }^{3}$. In a large study, CABG constitutes $17.5 \%$ of total amount of interventions 4

Although CABG is not preferred for the patients who have the history of CABG, PCI is on the forefront ${ }^{4}$. It is reported that $\mathrm{CABG}$ increases mortality and morbidity in the patients who have the history of PCI ${ }^{2,3}$. The difficulty of performing PCI to the patients with the history of CABG, however, has been voiced by many invasive cardiologists. But only a few studies have been conducted yet regarding this topic. In this study, we investigated the effect of performed $\mathrm{CABG}$ on subsequent percutaneous coronary interventions.

\section{MATERIAL AND METHODS}

\section{Study Population:}

Patients for whom PCI was applied between 2016-2018 years by one operator at Firat University School of Medicine Department of Cardiology were screened. One hundred patients (Group 1) who underwent percutaneous coronary intervention and had a history of PCI were included in the study. One hundred consecutive patients (Group 2) who had a history of CABG and underwent elective PCI in the same period were included in the study. Patients who underwent bifurcation stenting, CABG graft stenting, restenosis PCI, urgent revascularization or intervention to total occluded vessel were excluded. Necessary permission was obtained from local ethics committee for the study.

The essential demographic characteristics of the patients (age, gender, hypertension, diabetes, dyslipidemia, smoking and family history) were determined from patient registry data. It was determined to which vessel the intervention was applied. The time between the index intervention and the previous attempt was determined. The films from the digital records of the operations were watched by two experts, and QSA measured the degree of stenosis. The SYNTAX score was used to determine the degree of difficulty of the lesions. The lesions except the target lesion were ignored, and only the intervention vessel was calculated (Modified SYNTAX Score). 
In addition, as possible factors that make the intervention difficult; vascular access route, coronary anomaly (Yes-No), aortic root width (Normal-Wide), coronary tortuosity (Yes-No) and calcification (Yes-No), long lesion (>20mm), diffuse coronary artery disease (target lesion $\geq 20$ $\mathrm{mm}$ or at least two $>50 \%$ lesions other than the target lesion) are defined. Interventions made were evaluated in three groups as only balloon angioplasty group, balloon angioplasty plus stenting group and direct stenting group. As indicators of process difficulty, in the first grade; duration of intervention, the number of angiographic films and frames recorded, the amount of contrast agent used, and complications after the procedure were evaluated. In the second grade; the number of guide catheters used, the use of alternative catheters (Amplatz or EBU catheter requirement), the number of coronary guidewires used, the use of alternative wires (use of hydrophilic, intermediate, standard wires other than floppy), whether coronary balloon dilatation was performed or not before and after stent implantation, number of balloons used, amount of pressure applied to implant the balloon or stent were evaluated.

\section{Statistical Analysis:}

Data were analyzed using SPSS version 20.0 statistics package (SPSS Inc., Chicago, II, USA). Continuous variables were reported as mean $\pm \mathrm{SD}$ (standard deviation) and categorical variables were reported as percentages and counts. Student's t-test was used for comparison of normally distributed variables and Mann-Whitney
$\mathrm{U}$ test was used for non-normally distributed variables if 2 groups existed. Categorical variables were compared by $\chi 2$ test or Fisher's exact test, as appropriate. Pearson's correlation coefficients were used to assess strength of relationship between continuous variables and Spearman correlation analysis was performed for noncontinuous and categorical variables. Logistic regression analysis was used to determine the independent risk factors for CABG history. In all analyses, $\mathrm{p}$ value of $<0.05$ was considered statistically significant.

\section{RESULTS}

Group 1 and group 2 were similar in terms of age and gender $(64.28 \pm 7.54$ vs. $62.96 \pm 13.48$, $\mathrm{p}=0.45 ; 87$ male (\%87) vs. 75 male (\%75), $\mathrm{p}=0.09$, respectively). No statistically significant difference was observed between other demographic features (Table 1). All interventions were made from the femoral route. The lesion severity was not significantly different between the groups. In the CABG group, the intervention was more frequent to the circumflex artery $(\mathrm{Cx})$ lesion; while in the PCI group, intervention to the left anterior descending artery(LAD) lesion was more frequent (Table 2). Factors that made the procedure difficult were similar in both groups (Table 3). There was no significant difference between the two groups regarding lesions longer than $20 \mathrm{~mm}$ and diffuse coronary artery disease (p>0.05).

Table 1: Demographic Features of Patients

\begin{tabular}{|l|l|l|l|}
\hline & Group 1 (prior PCI) & Group 2 (prior CABG) & P value \\
\hline Age & $64.28 \pm 7.54$ & $62.96 \pm 13.48$ & 0.45 \\
\hline Gender(male) & $87 \%$ & $75 \%$ & 0.09 \\
\hline Hypertension & $65 \%$ & $63 \%$ & 0.53 \\
\hline Diabets & $35 \%$ & $37 \%$ & 0.62 \\
\hline Smoking & $65 \%$ & $66 \%$ & 0.79 \\
\hline Hyperlipidemia & $52 \%$ & $56 \%$ & 0.85 \\
\hline
\end{tabular}

Abbreviations: PCI: percutaneous coronary intervention, CABG: coronary artery bypass grafting. 
Table 2: Coronary Arteries of Intervention

\begin{tabular}{|l|l|l|l|}
\hline & Group 1 (prior PCI) & Group 2 (prior CABG) & P value \\
\hline LAD & $43 \%$ & $28 \%$ & 0.03 \\
\hline Cx & $32 \%$ & $43 \%$ & 0.04 \\
\hline RCA & $25 \%$ & $27 \%$ & 0.72 \\
\hline LMCA & $0 \%$ & $1 \%$ & 0.24 \\
\hline IM & $0 \%$ & $1 \%$ & 0.28 \\
\hline
\end{tabular}

Abbreviations: PCI: percutaneous coronary intervention, CABG: coronary artery bypass grafting, LAD: left anterior descending artery, Cx:circumflex artery , RCA:right coronary artery, LMCA:left main coronary artery, Im:intermediate artery.

Table 3: Factors that Difficult Intervention

\begin{tabular}{|l|l|l|l|}
\hline & Group 1(n) & Group 2(n) & P value \\
\hline Anomalous origin of coronary & 1 & 1 & 0.12 \\
\hline Aortic root dilatation & 11 & 9 & 0.25 \\
\hline Calcification & 27 & 29 & 0.24 \\
\hline Long lesions $(\geq \mathbf{2 0} \mathbf{~ m m )}$ & 35 & 37 & 0.50 \\
\hline $\begin{array}{l}\text { Diffuse coronary artery disease (Target lesion } \geq \mathbf{2 0} \mathbf{~ m m} \\
\text { or at least two lesions } \mathbf{5 0 \%} ; \text { except target lesions). }\end{array}$ & 43 & 49 & 0.65 \\
\hline Coronary tortuosity & 18 & 23 & 0.50 \\
\hline
\end{tabular}

Balloon dilatations and stentings were more frequent in former $\mathrm{CABG}$ group $(\mathrm{p}<0.05)$ and stenting without balloon dilation was more frequent in former PCI group $(\mathrm{p}<0.05)$. Balloon dilatation was more frequent in $\mathrm{CABG}$ group $(\mathrm{p}<0.05)$ (Table 4). The post-dilatation frequency was not different between the groups. The difference between the two groups regarding the number of guide catheters and wires used during the procedure was not significant. The interval between the prior $\mathrm{CABG}$ to index PCI was longer than the prior PCI to index PCI $(68.3 \pm 50.8$ vs. $16.3 \pm 23.7$ months, $\mathrm{p}<0.05)$. Index PCI duration was longer ( $18.1 \pm 11.2$ vs. $12.5 \pm 3.8 \mathrm{~min}, \mathrm{p}<0.05)$, radiopaque volume was higher $(54.4 \pm 27.0$ vs. $44.6 \pm 17.8 \mathrm{~mL}, \mathrm{p}<0.05)$, cine angiography film $(5.7 \pm 3.1$ vs. $4.4 \pm 1.6, \quad \mathrm{p}<0.05)$ and frame (209.2 \pm 107.6 vs. $171.8 \pm 62.6, \mathrm{p}<0.05)$ counts were higher in the prior CABG group (Table 5).

Table 4: Type of Intervention

\begin{tabular}{|c|c|c|c|c|c|c|c|c|}
\hline & & \multicolumn{6}{|c|}{ Percutan Coronary Intervention } & \multirow[t]{2}{*}{ Total } \\
\hline & & Balloon & P value & Stent & P value & Balloon+Stent & $P$ value & \\
\hline & $\begin{array}{l}\text { Group 1 } \\
\text { (prior PCI) } \\
\text { n, (\%) }\end{array}$ & $4(4 \%)$ & \multirow{2}{*}{0.04} & $74(74 \%)$ & \multirow{2}{*}{0.02} & $22(22 \%)$ & \multirow{2}{*}{0.03} & 100 \\
\hline & $\begin{array}{l}\text { Group 2 } \\
\text { (prior CABG) } \\
\mathrm{n},(\%)\end{array}$ & $10(10 \%)$ & & $58(58 \%)$ & & $32(32 \%)$ & & 100 \\
\hline Total & & 14 & & 132 & & 54 & & 200 \\
\hline
\end{tabular}

Abbreviations: PCI: percutaneous coronary intervention, CABG: coronary artery bypass grafting. 
Table 5: Content of Intervention

\begin{tabular}{|l|l|r|rr|}
\hline & Groups & \multicolumn{1}{|c|}{ Mean } & SS & P value \\
\hline Time of Intervention (months) & 1 & 16.13 & 23.74 & $0.001 *$ \\
\hline SYNTAX Score & 2 & 68.29 & 50.83 & \\
\hline & 1 & 3.76 & 2.17 & 0.993 \\
\hline Baloon Pressure (atm) & 2 & 3.69 & 1.98 & \\
\hline & 1 & 14.07 & 2.90 & 0.344 \\
\hline Scoping Time (minute) & 2 & 14.32 & 2.70 & \\
\hline & 1 & 12.53 & 3.83 & $0.001^{*}$ \\
\hline Number of Frame & 2 & 18.12 & 11.18 & \\
\hline & 1 & 171.75 & 62.58 & $0.039^{*}$ \\
\hline Number of Film & 2 & 209.20 & 107.58 & \\
\hline & 1 & 4.42 & 1.62 & $0.012^{*}$ \\
\hline Opaque Quantity (mL) & 2 & 5.67 & 3.05 & \\
\hline & 1 & 44.64 & 17.78 & $0.014^{*}$ \\
\hline
\end{tabular}

Patients in Group 1 who underwent elective PCI and had a history of PCI

Patients in Group 2 who had a history of CABG and underwent elective PCI

Prior CABG also has a significant correlation with prolonged intervention duration, radiopaque volume, and cine-angiography film and frame counts when controlling for intervened artery and prior index intervention time interval $(\mathrm{r}=0.316$ $\mathrm{r}=0.278 \mathrm{r}=0.321 \mathrm{r}=0.285$, respectively, $\mathrm{p}<0.01$ for all). When the complications observed after the procedure were compared according to the groups, the difference between the two groups was not significant (Table 6). According to logistic regression analysis, previous $\mathrm{CABG}$ history was found to be an independent variable for the duration of the procedure and the number of angiographic frames.

Table 6: Complications

\begin{tabular}{|l|l|l|l|}
\hline & Group 1 & Group 2 & P value \\
\hline Access Hematoma & 11 & 13 & 0.56 \\
\hline Acute stent thrombosis & 4 & 3 & 0.45 \\
\hline CoronaryDissection & 5 & 6 & 0.27 \\
\hline Hypotension & 14 & 11 & 0.26 \\
\hline Allergy & 1 & 1 & 0.33 \\
\hline Arrhytmia & 13 & 14 & 0.54 \\
\hline Embolia & 0 & 0 & 0.65 \\
\hline Contrast Nephropathy & 1 & 2 & 0.66 \\
\hline
\end{tabular}

\section{DISCUSSION}

In our study, it was found that percutaneous coronary interventions applied to patients with CABG were longer, had more contrast agent used during the procedure, had a more significant number of angiographic film and frames taken during the intervention. The risk of need for reoperation in follow-up continues in patients who have undergone CABG surgery. Native coronary artery atherosclerosis, grafting problems, severe mediastinal adhesions and epicardial scarring 
complicate the repetitive surgical procedure by disrupting the coronary anatomy. The mortality rates in recurrent surgeries are higher than in the first operations 5. However, no significant difference was found between the two groups in our study. But in patients with CABG, the time from $\mathrm{CABG}$ to the index PCI was longer than the control group. This suggests the possibility that atherosclerosis has advanced.In the follow-up of the patients after CABG surgery, approximately $80 \%$ of patients after five years and $63 \%$ of patients after ten years remain without angina ${ }^{6}$. In our study, the percutaneous coronary intervention was performed 68 months after surgery on average to the patients in CABG group.The percutaneous coronary intervention was completed after 16 months on average to the patients in PCI group.

The vessel being treated, whether the procedure is urgent or elective, the degree of occlusion and the complexity of the lesion are also useful on the outcomes of the procedures 7 . In our study, while the other factors were similar in both groups, the vessel being treated was found to be significantly different. This suggests that it may be due to the long patency rates of the internal mammary artery grafts and the preference of CABG for the patients with left anterior descending artery lesions. Although this effect was favorable to the control group, the correlation analysis showed that the difficulty of the procedure was higher in patients with CABG. Possible reasons for increased procedural difficulty in CABG patients may be the fact that patients with diffuse disease and a technical problem about PCI were referred to $\mathrm{CABG}$ at the beginning. To limit the effects of these potential factors; aortic root width, coronary tortuosity, coronary calcification, $20 \mathrm{~mm}$ lesion length and diffuse coronary artery disease and additional difficulties encountered during coronary angiography were evaluated and found to be not significantly different between the groups. These findings support that both groups are similar regarding lesion difficulty, except CABG factor. Another possible cause is a progression of atherosclerosis over time. In our study, the time from the CABG to the index procedure was found more than the time from PCI to index procedure. This result is in agreement with the fact that the need for revascularization after $\mathrm{CABG}$ is less and later than PCI ${ }^{8}$. However, partial correlation analysis to limit the effect of this difference showed that the relationship of CABG to the PCI difficulty was independent of the time factor.
In our study, direct stenting was more frequent in patients with PCI group, whereas patients in $\mathrm{CABG}$ group had more frequent dilatation with a coronary balloon before stenting during the procedure. More prevalence of dilatation in the CABG group has been considered due to the increase in the difficulty of the lesion for PCI because of mediastinal adhesions, epicardial scar tissue and ongoing persistence of atherosclerosis in native coronary arteries following $\mathrm{CABG}$ surgery. Another possible cause is the potential adverse effects of CABG on the development of coronary atherosclerosis. Studies have reported that atherosclerotic progression, total occlusion, grade of initial lesion, type of interventional treatment, and the time after treatment are essential determinants of atherosclerosis progression in CABG patients ${ }^{4}$. After CABG, the disease progression in native coronary vessels is $20 \%$ to $40 \%$ within 5 to 10 years ${ }^{4}$. The rate of disease progression is 3 to 6 times higher in grafted native coronary arteries than in ungrafted ones 9. In particular, the progress of atherosclerotic lesions proximal to the anastomotic site after $\mathrm{CABG}$ is more frequent than the lesions of same severity in unoperated vessels in the first year, whether the graft is open or not. This is considered to be a consequence of increased blood supply to the myocardium ${ }^{5}$. In a study by Maurer BJ et al. ${ }^{9}$, the causes of increased atherosclerosis progression have been discussed. These are defined as newly formed atherosclerosis or progression of atherosclerosis in the old lesions associated with an operation by an unknown cause. Potential causes are surgical manipulation, reduction of blood flow, predisposition to thrombus formation and endothelial injury with the retrograde flow to the proximal coronary arteries from the graft which causes turbulence flow between the proximal and distal currents. These possible causes have not been investigated in our study. Evaluation of vessel walls, lesion characteristics with intravascular ultrasound (IVUS) or optic coherence tomography (OCT) may provide more information about why PCI is more difficult in CABG patients by showing the possible mechanisms like increased fibrosis and calcification.

There was no difference between the two groups regarding the number and variety of catheters and guidewires used during the procedure, which was an indirect indicator of difficulty. Complications such as no reflow, coronary perforation and rupture may be observed in percutaneous coronary interventions. In our study, there was no 
significant difference between the two groups regarding no-reflow, coronary perforation, and rupture. And these complications are seen in limited numbers. SYNTAX scoring system provides essential data in the evaluation of coronary artery bed, considering angiographic features such as some lesions, functional importance and lesion placement ${ }^{7}$. This scoring system has been prepared for the study named "synergy between PCI with TAXUS and cardiac surgery" (SYNTAX), which is planned to determine the most appropriate treatment strategy in patients with three vessels and left main coronary artery lesions ${ }^{7}$. In our study, the SYNTAX score was calculated only for the coronary artery to which percutaneous coronary intervention was planned. There was no statistically significant difference between the two groups regarding the syntax score. Because the SYNTAX scores were similar between the two groups, it was thought that intervention made coronary vessels were identical regarding percutaneous coronary intervention difficulty. Further, there was no difference in the balloon pressures applied while stenting in both groups. When considered with the more many dilatations in CABG group, it can be stated that dilatation facilitates stent implantation, allowing higher pressures and removes the need for postdilatation. Low Modified Syntax Score and low complication rate are associated with the low lesion complexity and also pure lesions.

In our study, it is not investigated why PCI procedure lasted longer in $\mathrm{CABG}$ patients. Possible reasons for this may be the preference of CABG in patients with more difficult lesions and the increased complexity of the lesion in the ongoing atherosclerotic process, as discussed above. Another possible cause is accelerated fibrosis and calcification with the opening of the pericardium. In our study, groups were similar regarding angiographic observation of calcification, but further studies with IVUS or OCT to demonstrate lighter calcification and fibrosis may be enlightening. Related studies also support it found that mediastinal adhesions and epicardial scar development disrupt coronary anatomy in patients who underwent CABG surgery ${ }^{10}$.

\section{Limitations:}

Our study is a retrospective. It is a limitation that information is taken from records. Medical treatments taken by patients in the study, history of other diseases were not studied. Another limitation is the low number of samples.

\section{CONCLUSION}

In patients with coronary artery bypass grafting, percutaneous coronary intervention procedures take more extended, more contrast medium is used, and there is more exposure to radiation. Considering this situation, taking precautions such as hydration, keeping appropriate, adequate and alternative materials when performing PCI to the patients with $\mathrm{CABG}$ history may be helpful in increasing the success of the procedure and reducing complications.

\section{REFERENCES}

1.Murray CJ, Lopez AD. Mortality by cause for eight regions of the world: Global Burden of Disease Study. Lancet 1997;349:1269-76.

2.Brilakis ES, Rao SV, Banerjee $\mathrm{S}$, et al. Percutaneous coronary intervention in native arteries versus bypass grafts in prior coronary artery bypass grafting patients: a report from the National Cardiovascular Data Registry. JACC Cardiovasc Interv. 2011;4(8):844-50. 3.Mannacio V, Di Tommaso L, De Amicis V, et al. Previous percutaneous coronary interventions increase mortality and morbidity after coronary surgery. Ann Thorac Surg. 2012;93(6):1956-62.

4.Yusuf S, Zucker D, Peduzzi P, et al. Effect of coronary artery bypass surgery on survival: an overview of 10-year results from randomized trials by the Coronary Artery Bypass Graft Surgery Trialists Collaboration. Lancet 1994;344(8922):563-70.

5.Eagle KA, Guyton RA, Davidoff R, et al. ACC/AHA Guidelines for Coronary Artery Bypass Graft Surgery: A Report of the American College of Cardiology/American Heart Association Task Force on Practice Guidelines (Committee to Revise the 1991 Guidelines for Coronary Artery Bypass Graft Surgery). American College of Cardiology/American Heart Association. J Am Coll Cardiol. 1999;34(4):1262347.

6.Loop F, Lytle B, Cosgrove D,et al. Influence of the Internal Mammary Artery Graft on 10-Year Survival and Other Cardiac Events. NEJM 1986; 314: 1-6.

7.Sianos G, Morel M, Kappetein A, et al. The SYNTAX score: an angiographic tool grading the complexity of coronary artery disease. EuroIntervention 2005; 1: 219-27. 
8.Wijns W, Kolh P, Danchin N, et al. Task Force on Myocardial Revascularization of the European Society of Cardiology (ESC) and the European Association for Cardio-Thoracic Surgery (EACTS); European Association for Percutaneous Cardiovascular Interventions (EAPCI), Guidelines on myocardial revascularization. Eur Heart J. 2010;31(20):2501-55.

9.Maurer BJ, Oberman A, Holt JH Jr, et al. Changes in grafted and nongrafted coronary arteries following saphenous vein bypass grafting. Circulation 1974;50: 293-300.

10.Accola KD, Craver JM, Weintraub WS, et al. Multiple preoperative coronary artery bypass grafting. Ann Thorac Surg 1991;52:738-43. 